\title{
PHOSPHATE SEQUENCE STUDY OF BOQUEIRÃO PEGMATITE (RIO GRANDE DO NORTE STATE, BRAZIL)
}

\author{
Sandra Amores Casals ${ }^{1}$ \\ Sandra de Brito Barreto ${ }^{2}$ \\ Ruben Espallargas ${ }^{3}$ \\ François Fontan ${ }^{4}$ \\ Joan Carles Melgarejo Draper ${ }^{5}$
}

\author{
${ }^{1,5}$ Departament de Cristalografia, Mineralogia i Dipòsits Minerals. Facultat de Geologia, \\ Universitat de Barcelona-Spain; sandra.amores@ub.edu; \\ joan.carles.melgarejo.draper@ub.edu \\ ${ }^{2}$ Departamento de Geologia, Universidade Federal de Pernambuco,Recife (Pernambuco, \\ Brasil).sandradebritobarreto@gmail.com \\ ${ }^{3}$ Institut de Ciencies de la Terra Jaume Almera (ICTJA-CSIC). Barcelona Spain. \\ respallargas@ictja.csic.es \\ ${ }^{4}$ CNRS-Université Paul Sabatier, Toulouse (France).
}

\section{RESUMO}

O pegmatito Boqueirão localiza-se naProvíncia Pegmatítica daBorborema, no estado do Rio Grande do Norte (Nordeste do Brasil), encontra-se encaixado em metaconglomerados de idade neoproterozóicada Formação Equador. Trata-se de um pegmatito zonado concentricamente, exibindo diferentes zonas caracterizadas por suas mineralogias. As zonas de contato e de parede são compostas essencialmente por quartzo, microclina e moscovita exibindo muitas vezes texturas esqueléticas e gráficas, e,tendo como minerais acessórios a turmalina e a granada. A zona intermediária é dividida em duas subzonas distintas e mostra uma mineralogia diversa exibindo uma complexa associação de fosfatos, berilo, columbita-tantalita e zircão. A zona mais interna é principalmente constituída por um núcleo de quartzo. Além disso, observa-se corpos de substituição típicos, constituídos por albita,situados na parte oriental do corpo. Litofilita - triplilita representa a fase de fosfato mais abundante exibindo exsoluções de sarcopsida e substituição por sicklerita, resultante da alteração por Lilixiviação, mais conhecida como Série de Quensel-Mason. A ausência de membros da série heterosita-purpurita é notável. Fosfatos primários, tais como montebrasita e triplita são também observados. Subsequentemente, a presença de alluaudita e varulita sugere que o pegmatito foi submetido a metassomatismo sódico.Toda esta assembléia de minerais sofreu uma extensa alteração que levou a cristalização de fosfatos secundários. Dados de microssonda eletrônica em trifilita-litiofilita revelam razões $\mathrm{Mn} /(\mathrm{Mn}+\mathrm{Fe})$ entre 0,21-0,24 e também até 0,72 que sugerem um magma de origem pouco fracionado; consequentemente, a ferrisicklerita mostra valores de $\mathrm{Mn} /(\mathrm{Mn}+\mathrm{Fe})$ entre 0,69-0,77, característicos de elevado grau de evolução, sugerindo que o pseudomorfismo foi produzido por uma elevada interação entre rocha/fluido. Alluaudita e varulita também revelam conteúdos de $\mathrm{Mn}$ e Fe até 0,71 semelhantes aos fosfatos precursores. Além disso, oito diferentes fosfatos secundários foram identificados substituindo fases primárias, quer como pseudomorfos ou cortando-as. Ocorrem como cristais euédricos de grã fina, esferulíticos ou maciços, com cores vivas facilmente identificados. As fases secundárias ricas em Mn são hureaulita, eosphorita, whiteita, jahnsita e serrabrancaita, enquanto que lipscombita, phosphosiderita e mitridatita 


\section{Sandra Amores Casals et al.}

correspondem a associação secundária rica em ferro $(\mathrm{Fe})$. A origem supergênica tardia e a entrada fluidos ricos $\mathrm{Ca}, \mathrm{K}$ e $\mathrm{Mg}$ procedentes da rocha hospedeira são sugeridos como responsáveis pela formação destes fosfatos. Não há quaisquer feições que os correlacionem a cristalização do pegmatito. O conteúdo de Háfnio (Hf) de zircões encontrados na zona intermediária tem sido analisado por microssonda eletrônica, e, usado como um poderoso indicador do grau de evolução do pegmatito, juntamente com o conteúdo de Mn dos fosfatos. O conteúdo Hf obtido é baixo chegando até $5 \%$ em peso de $\mathrm{HfO}_{2}$, que revela um magma pegmatítico pouco fracionado. Além disso, a presença de silicatos ferromagnesianos que constituem a mineralogia de zonas do pegmatito, como a turmalina rica em $\mathrm{Fe}$, a granada e o berilo verde está de acordo com esta hipótese. Portanto, o Pegmatito Boqueirão corresponde a um pegmatito de elementos raros subtipo berilo-columbita-fosfato.

Palavras chave: Pegmatitos graníticos, fosfato, Boqueirão, Brasil.

\section{ABSTRACT}

The Boqueirão pegmatite is located in the Borborema Pegmatite Province in the state of Rio Grande do Norte (NE Brazil) hosted by Neoproterozoic metaconglomerates of Equador Formation. The pegmatite occurs as a concentric body displaying characteristic units according their mineralogy. The border and wall zones are composed by quartz, microcline and muscovite often displaying skeletal and graphic textures with accessory tourmaline and garnet. The intermediate zone is divided in two distinct subzones and shows a complex mineralogy exhibiting a varied phosphate association, beryl, columbite-tantalite and zircon. The innermost zone is mainly constituted by a quartz core. In addition, typical replacement bodies of albite are recognized at the eastern part of the body. Lithiophilite - triphylite represents the most abundant phosphate phase exhibiting exsolutions of sarcopside and replaced by sicklerite due to Li-leaching alteration, best known as Quensel Mason sequence. The scarcity of heterosite-purpurite series is remarkable. Montebrasite and triplite are also primary phosphates observed. Subsequently, the presence of alluaudite and varulite occurrences suggests that Na-metasomatism affected the pegmatite. The whole ensemble is crosscut by an extensive alteration that resulted in secondary phosphate minerals. Electron microprobe data of triphylite-lithiophilite shows $\mathrm{Mn} /(\mathrm{Mn}+\mathrm{Fe})$ ratios between 0.21-0.24 but also up to 0.72 which seems to indicates that the earlier pegmatite magma could be slightly fractionated; consequently, ferrisicklerite shows $\mathrm{Mn} /(\mathrm{Mn}+\mathrm{Fe})$ values between 0.69-0.77 in agreement with high evolution degree and suggesting that pseudomorphism may be produced by high rock/fluid ratios. Alluaudite and varulite also record $\mathrm{Mn}$ and Fe contents up to 0.71 similar to precursor phosphates. Furthermore, eight different secondary phosphates have been identified as replacement of primary phases either as pseudomorphs or crosscutting them. They form euhedral crystals of fine grain size, spherulites or extensive masses displaying vivid colours which are easily identifiable. Mn-rich secondary phases are hureaulite, eosphorite, whiteite, jahnsite and serrabrancaite while lipscombite, phosphosiderite and mitridatite correspond to Fe-rich secondary association. Supergenic late origin and entrance of Ca-, $\mathrm{K}-$, Mg-rich fluids from host rock may be invoked in order to explain their formation. They do not show any relationship with processes of pegmatite crystallization. Hf content of zircon from the intermediate zone has been analysed by electron microprobe as a powerful indicator of pegmatite evolution degree together with $\mathrm{Mn}$ content of phosphates. Hf content obtained is low up to $5 \%$ wt. of $\mathrm{HfO}_{2}$ which points out to low 
fractionated pegmatite magma. Besides, the presence of ferromagnesian silicates forming the pegmatite units such as Fe-rich tourmaline, garnet and green beryl is in agreement of that hypothesis. Therefore, Boqueirão corresponds to rare element pegmatite of beryl-columbite-phosphate subtype.

Keywords: Granitic pegmatite, phosphate, evolution, Boqueirão, Brazil.

\section{INTRODUCTION}

The Boqueirão pegmatite is located in the state of Rio Grande do Norte, Northeastern Brazil and belongs to Borborema Pegmatitic Province (BBP). The BBP is known since the beginning of $20^{\text {th }}$ century for mica extraction and during the Second World War it became best known not only as one of the most important Ta-Be producers but also for its exotic $\mathrm{Nb}-\mathrm{Ta}$ oxide production (Beurlen et al., 2008). Recently, it became an important supplier of raw material for the Brazilian ceramics industry (Beurlen et al., 2009). In Boqueirão, feldspars and micas have been mined together with different amounts of beryl and Ta-bearing minerals as sub products. In addition, phosphate nodules are frequent. As mentioned in previous studies, rareelements mineralization has been associated to phosphates, therefore, its presence could be a good criterion for field exploration (Černý et al., 1997: London, 2008).

In spite of last century importance, very few geological studies were performed about the BPP in the last fifty years. The aim of this contribution is to establish a paragenetic sequence and mineral chemistry of primary, metasomatic and secondary phosphates in order to evaluate the degree of evolution of the pegmatite and to establish the processes that operated during the formation of Boqueirão pegmatite.

\section{GEOLOGICAL SETTING}

Boqueirão pegmatite is located near the city of Parelhas in the state of Rio Grande do Norte, Brazil. It is hosted in a geotectonic region best known as Borborema Province (Fig. 1), which comprises the west-central part of a Pan African-Brasiliano tectonic collage that formed as a consequence of late Neoproterozoic (ca. 600 Ma) assembly of West Gondwana (Van Schmus et al., 2003). Most of the province consists of Paleoproterozoic to Archean basement blocks with Neoproterozoic metasedimentary and metavolcanic sequences forming major fold belts, and voluminous plutonic magmatism. The eastern part of the province can be divided into three major tectonic domains: the Rio Grande do Norte domain (RGND), to the north of the Patos shear zone; a central domain between the Patos and Pernambuco shear zones; and a southern domain (SD) between the Pernambuco shear zone and the São Francisco craton (SFC). The western part may be divided into two main tectonic domains: Ceará and Médio Coreau domain. The area covered in this work is located in the southeastern part of Seridó fold belt (Beurlen et al., 2008). Seridó fold belt comprises two essential units, basement and metasedimentary sequences known as the Seridó Group (Soares et al., 2008). Neoproterozoic basement is formed by Caicó Complex composed by gneisses and migmatites formed around $2.2 \mathrm{Ga}$, and Sao Vicente Complex composed by schist, quarzites, amphybolites and marbles (Baumgartner et al., 2006). 
Seridó Group is composed by supracrustal rocks formed during the Meso- and Neoproterozoic, discordantly over the Paleoproterozoic Caicó Complex $(2.2 \mathrm{Ga})$. It is divided into three formations from the bottom to the top of Jucurutú formation constituted for biotite-rich gneisses interlayered with limestone or calc silicate beds. Equador formation is composed for muscovite-rich quartzite, in addition of polimictic metaconglomerates, gneisses, schists, marbles and calcsilicate rocks at the top. On the top, Serido Formation is represented by aluminous metapelites with variable amounts of garnet, cordierite, staurolite, andalusite and sillimanite. The Boqueirão pegmatite is intruding quartzites, metarkoses and metaconglomerates of the Equador Formation, as about $11 \%$ of mineralized rare-element granitic pegmatites of Borborema Province (Beurlen et al., 2008).

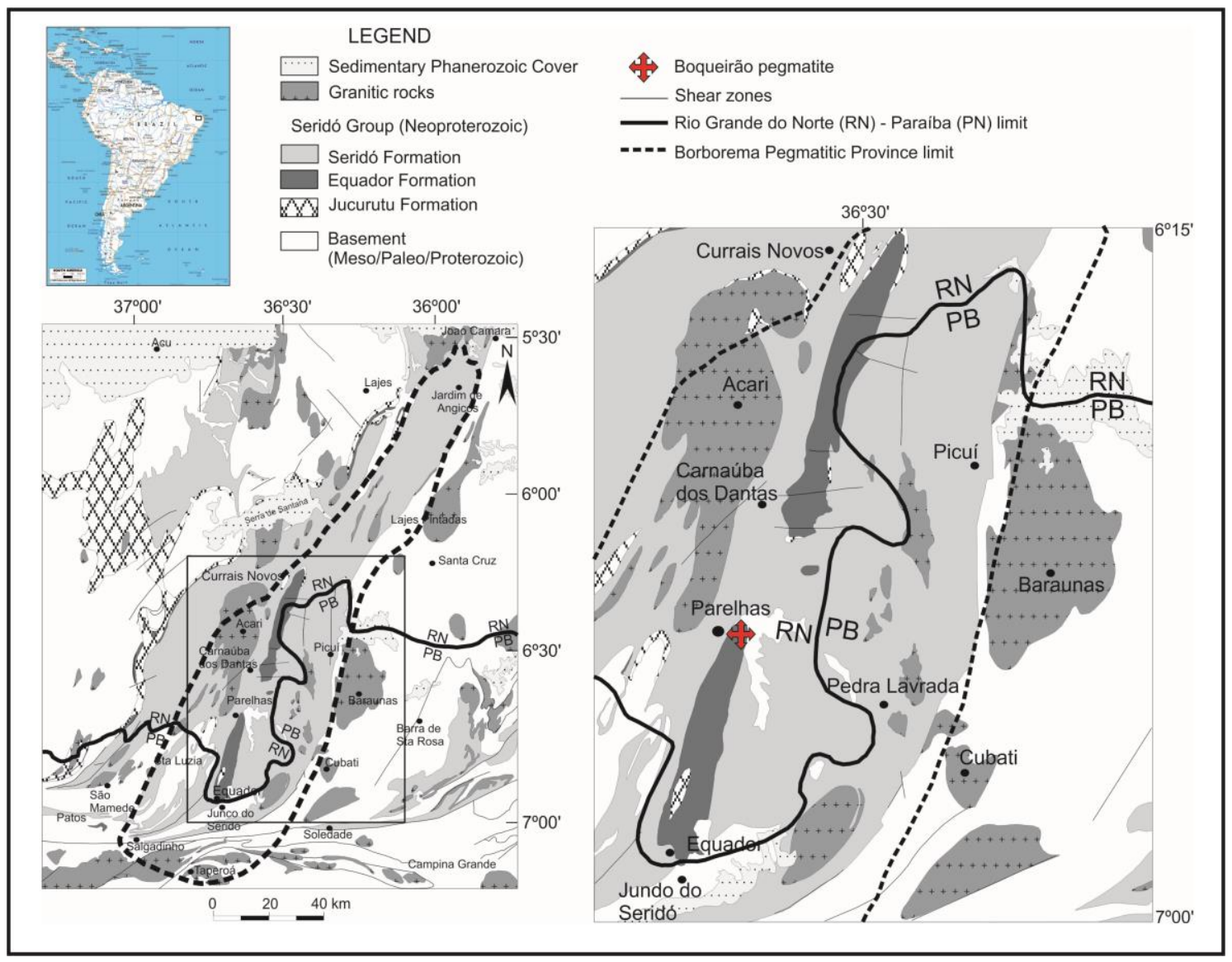

Figure 1- Location and geological setting of the Boqueirão pegmatite (BP) inside the Borborema Pegmatitic Province. The BP is hosted by the Neoproterozoic Equador Formation. Modified after Soares et al. (2011).

\section{ANALYTICAL METHODS}

A sequence of transmited-reflected optical mineralogy and electron microprobe analyses was used to identify phosphate minerals. Quantitative analyses of major elements were performed with wavelengthdispersive spectrometry (EMPA-WDS) using a CAMECA SX-100, by analysts Dr. De Parseval and Dr. Fontan, at Laboratoire de Minéralogie at Paul Sabatier University (Toulouse, France) and a CAMECA SX-50 at Centres Científics i Tecnològics of the University of Barcelona by Dr. Llovet. 
Operating conditions were accelerating voltage of $15 \mathrm{kV}$ was combined with a beam current of $15 \mathrm{nA}$ and $2 \mu$ spot beam diameter. The structural formulae of phosphates were calculated based on (PO4) ${ }^{3-}$ tetrahedron. Calculation of other components such as $\mathrm{H}_{2} \mathrm{O}, \mathrm{F}$ and $\mathrm{Fe}^{3+}$ was done using charge balance and stoichiometry.

\section{STRUCTURE OF BOQUEIRÃO PEGMATITE}

Boqueirão pegmatite is a thick dyke 50 metre wide exposed over a distance of $400 \mathrm{~m}$, striking approximately NW-SE crosscutting metaconglomerates of Equador Formation and presenting or developing tourmalinization around its contact. Concentric units are only observed in the central part of the pegmatite, whereas the western part is poorly zoned or unzoned. Those units are distinguished by different mineralogy and mineral textures following the usual nomenclature for pegmatite zoning according to Cameron (1948) and Černý (1991) criteria in: border and wall zone, outer and inner intermediate zone and quartz core (Fig. 2).

The outer zones are mainly composed by a border and a wall zone with fine grain quartz and muscovite. Graphic intergrowth and equigranular textures develop in the wall zone. Other minor minerals such as schorl, garnet and occasionally löllingite, sometimes associated with bismuthinite, are present.

The intermediate zone is divided in two subzones: the first one (A), in the outer part, is characterized by intergrowth between perthitic white microcline with exsolved grey quartz giving rise graphic texture with additional amounts of albite, muscovite, beryl, sometimes columbite-tantalite group minerals and commonly zircon. B intermediate zone has coarser grain size forming one-meter-long crystals. The mineralogy is more complex than previous units and consists of quartz, perthitic microcline, albite, muscovite, phosphates (Fig. 3a), beryl, columbitetantalite group minerals and zircon (Fig. 5f). Phosphate minerals occur as nodular or skeletal morphology with complex and little-known paragenetic relationships. The innermost part is essentially constituted by quartz (Fig. 3b).

Typical replacement bodies are recognized highly developed at the eastern part, where an association of fine-grained saccharoidal albite (Fig. $5 \mathrm{~h}$ ), muscovite and quartz generates a total replacement of wall and intermediate zones (Fig. 2 and 3b). In addition, albite veins are observed throughout the whole pegmatite as well as quartz-muscovite veinlets (Fig. 3c). 


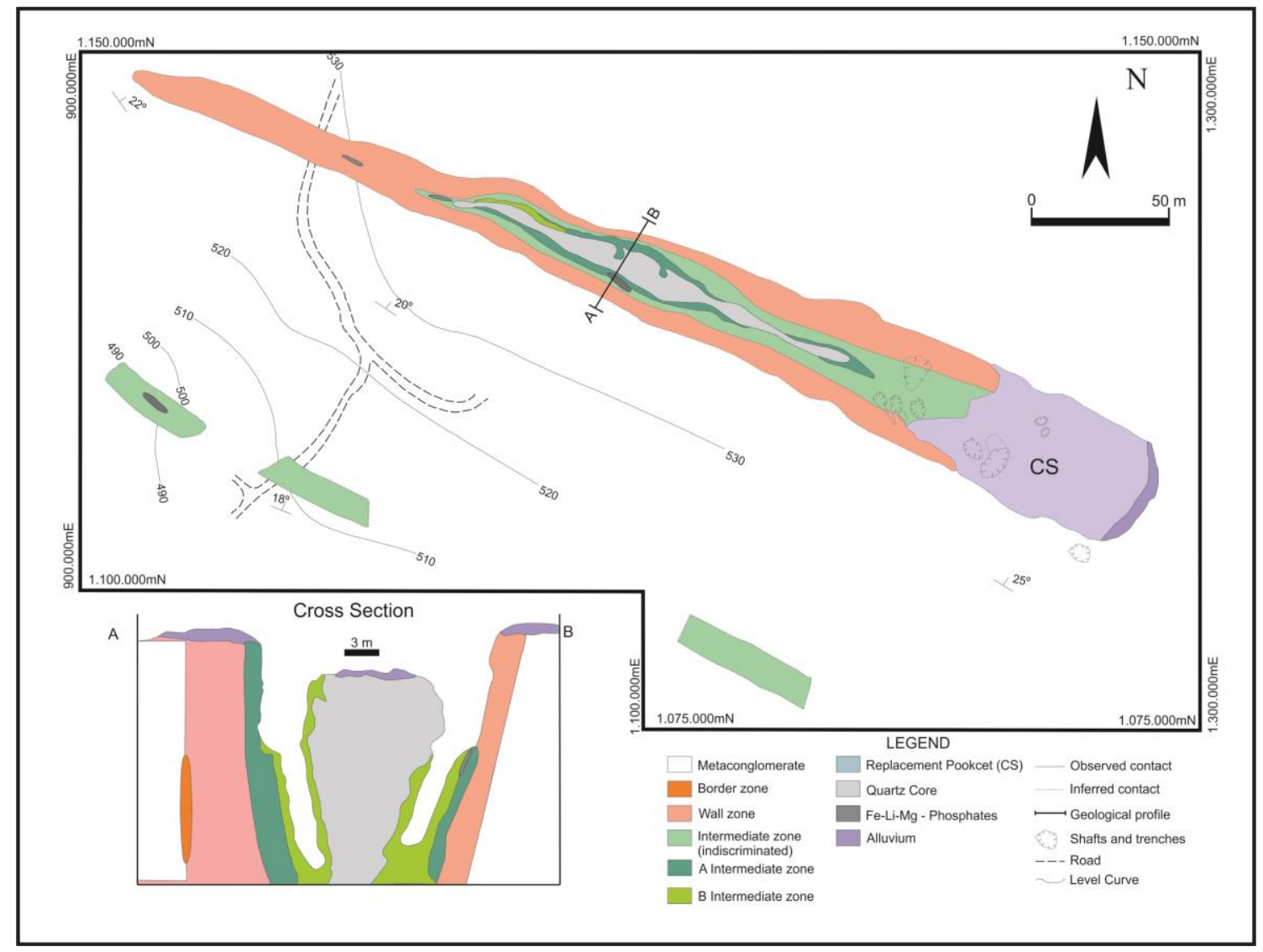

Figure 2: Sketch of Boqueirão pegmatite inner structure. The main units are represented; border zone (orange), wall zone (pink), intermediate zone (two different green) and the quartz core (grey) with replacement bodies. Modified from Beurlen et. al (2008).
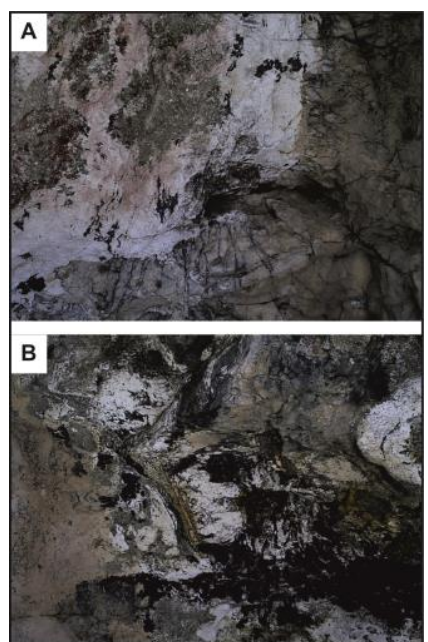

Figure 3: A) Phosphate crystals with coarse grain size, at intermediate zone; B) albite replacement bodies (white and rose colored) overlapping intermediate zone; C) detail of quartz-muscovite late veinlets.

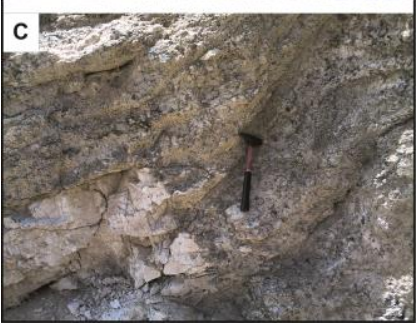




\section{PETROGRAPHY MINERAL CHEMISTRY}

AND

According to Moore phosphate classification, primary, metasomatic and secondary phosphates have been identified composing the $\mathrm{B}$ intermediate zone (Fig. 4).

\section{Primary phosphates}

Triphylite - lithiophilite are the most abundant minerals and constitutes nodular greenish-grey equidimensional crystals. They are usually intergrown with two generation of sarcopside: the first one commonly appears as fine grain exsolution ( $3 \mu \mathrm{m}$ long) regularly parallel arranged in triphylite crystals. The second generation is constituted by $1 \mathrm{~mm}$ long crystals with randon orientation near the crystal rims or fractures (Fig. 5a). Triphylite lithiophilite are often replaced following Li-leaching, by ferrisicklerite sicklerite, heterosite - purpurite and alluaudite in a process best known as Quensel - Mason Sequence (Fontan et al., 1976; Corbella and Melgarejo,
1990; Hatert et al., 2006). Ferrisicklerite-sicklerite is easily identifiable under microscope as orange crystals with visible exfoliation and pleochroism, maintaining optical continuity with previous lithiophilitetriphylite crystals that grows inside them (Fig. 5b, c). Heterosite-purpurite is extremely scarce. Triplite and amblygonite form allotriomorfic equidimensional crystals of several decimeters long replaced by secondary phosphates and manganese oxides. Amblygonite is less abundant.

Triphylite - lithiophilite composition show variable $\mathrm{Mn}$ and $\mathrm{Fe}$ content. Based on that, in the Mn-rich triphylite the ratio $\mathrm{Mn} /(\mathrm{Mn}+\mathrm{Fe})$ varies between $0.21-0.24$ and in the Fe-rich lithiophilite this ration reaches 0.72 . Ferich sarcopside exsolutions display low $\mathrm{Mn} /(\mathrm{Mn}+\mathrm{Fe})$ ratio between 0.23 and 0.24 which remain similar to Mn-rich triphylite ratio (Fig. 5). Sicklerite has high $\mathrm{Mn} /(\mathrm{Mn}+\mathrm{Fe})$ ratios between 0.69 and 0.77 suggesting that this replacement may be produced by high rock/fluid ratios.

\begin{tabular}{|c|c|}
\hline \multicolumn{2}{|r|}{ Primarv phosphates } \\
\hline Triphylite - lithiophilite & $\mathrm{Li}(\mathrm{Fe}, \mathrm{Mn})^{2+} \mathrm{PO}_{4}$ \\
\hline Sarcopside & $\left(\mathrm{Fe}^{2+}, \mathrm{Mn}^{2+}, \mathrm{Mg}\right)_{3}\left(\mathrm{PO}_{4}\right)_{2}$ \\
\hline Triplite & $\left(\mathrm{Mn}^{2+}, \mathrm{Fe}^{2+}\right)_{2}\left(\mathrm{PO}_{4}\right)(\mathrm{F}, \mathrm{OH})$ \\
\hline Amblygonite - montebrasite & $\mathrm{LiAl}\left(\mathrm{PO}_{4}\right)(\mathrm{F}, \mathrm{OH})$ \\
\hline Ferrisicklerite - sicklerite & $\mathrm{Li}_{1-\mathrm{x}}\left(\mathrm{Mn}_{1-\mathrm{x}}{ }^{2+}, \mathrm{Fe}_{\mathrm{x}}^{3+}\right) \mathrm{PO}_{4}$ \\
\hline Heterosite - purpurite & $(\mathrm{Fe}, \mathrm{Mn})^{3+} \mathrm{PO}_{4}$ \\
\hline \multicolumn{2}{|r|}{ Metasomatic phosphates } \\
\hline Alluaudite & $\mathrm{NaCaFe}^{2+}\left(\mathrm{Mn}^{2+}, \mathrm{Fe}^{2+}, \mathrm{Fe}^{3+}, \mathrm{Mg}\right)_{2}\left(\mathrm{PO}_{4}\right)_{3}$ \\
\hline Varulite & $\mathrm{NaCaMn}{ }^{2+}\left(\mathrm{Mn}^{2+}, \mathrm{Fe}^{2+}, \mathrm{Fe}^{3+}\right)_{2}\left(\mathrm{PO}_{4}\right)_{3}$ \\
\hline \multicolumn{2}{|r|}{ Secondarv phosphates } \\
\hline Hureaulite & $(\mathrm{Mn}, \mathrm{Fe})^{2+}{ }_{5}\left(\mathrm{PO}_{4}\right)_{2}\left(\mathrm{HPO}_{4}\right)_{2} \cdot 4 \mathrm{H}_{2} \mathrm{O}$ \\
\hline Eosphorite & $\left(\mathrm{Mn}^{2+} \mathrm{Al}\left(\mathrm{PO}_{4}\right)(\mathrm{OH})_{2} \cdot\left(\mathrm{H}_{2} \mathrm{O}\right)\right.$ \\
\hline Whiteite & $\mathrm{Ca}\left(\mathrm{Fe}, \mathrm{Mn}^{2+}\right) \mathrm{Mg}_{2} \mathrm{Al}_{2}\left(\mathrm{PO}_{4}\right)_{4}(\mathrm{OH})_{2} \cdot 8 \mathrm{H}_{2} \mathrm{O}$ \\
\hline Jahnsite & $\mathrm{CaMn}^{2+} \mathrm{Fe}_{2}{ }^{2+} \mathrm{Fe}_{2}{ }^{3+}\left(\mathrm{PO}_{4}\right)_{4}(\mathrm{OH})_{2} \cdot 8 \mathrm{H}_{2} \mathrm{O}$ \\
\hline Lipscombite & $\left(\mathrm{Fe}_{2+}, \mathrm{Mn}^{2+}\right) \mathrm{Fe}_{2}^{3+}{ }_{2}\left(\mathrm{PO}_{4}\right)_{2}(\mathrm{OH})_{2}$ \\
\hline Phosphosiderite & $\mathrm{Fe}^{3+} \mathrm{PO}_{4} \cdot 2 \mathrm{H}_{2} \mathrm{O}$ \\
\hline Mitridatite & $\mathrm{Ca}_{2} \mathrm{Fe}_{3}{ }^{3+}\left(\mathrm{PO}_{4}\right)_{2} \mathrm{O}_{2} \cdot 3 \mathrm{H}_{2} \mathrm{O}$ \\
\hline
\end{tabular}

Figure 4: Chemical composition of phosphate occurrences which are present in the Boqueirão pegmatite. 

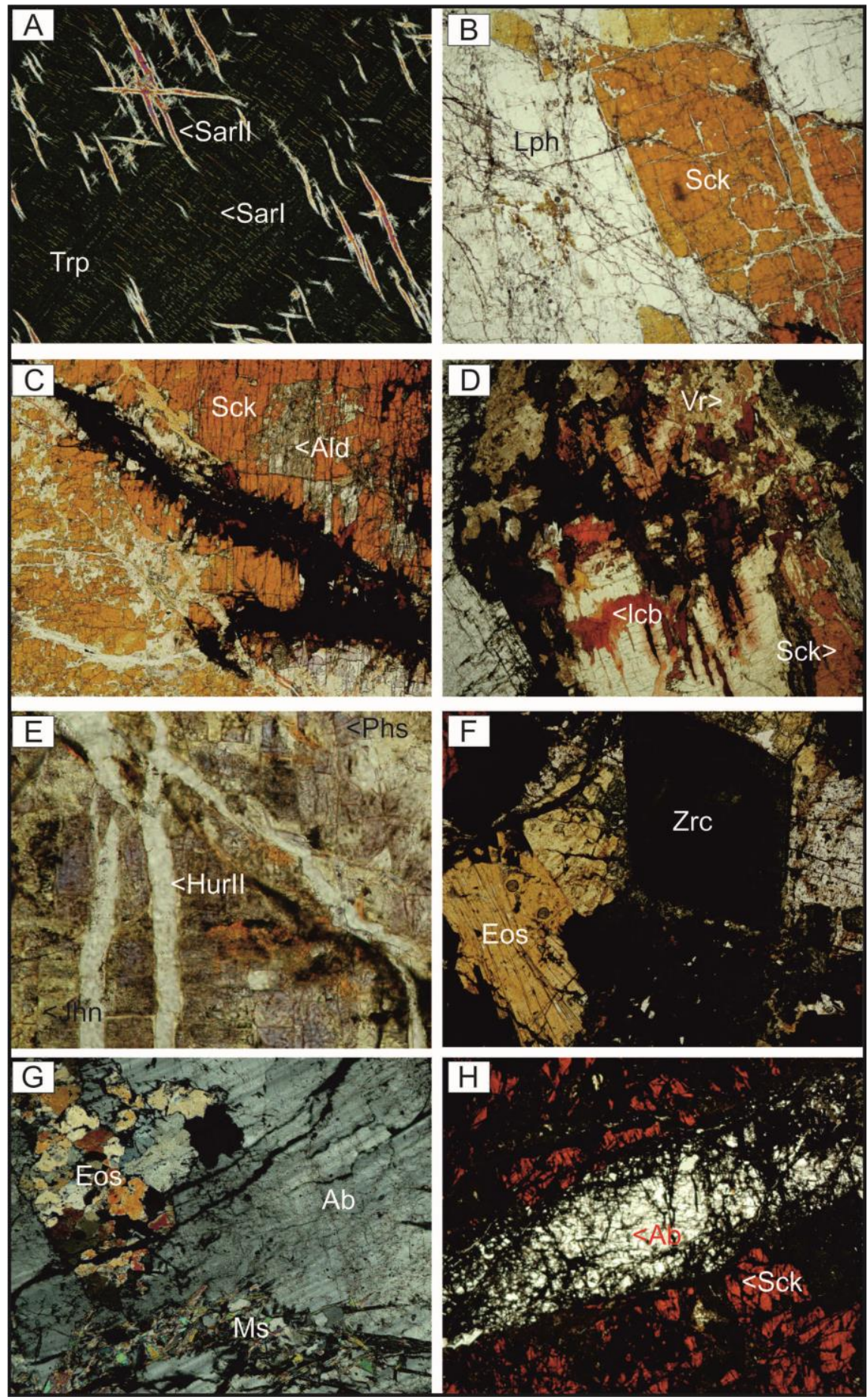

Figure 5. Images of different phosphate associations obtained by transmitted light microscope. A) Triphylite (Trp) with two generation of sarcopside exsolutions (Sar) (x5, xp); B) lithiophilite (Lph) replaced by sicklerite (Sck) (x2, pp); C) Sicklerite crystals (reddish orange) replaced by yellowish alluaudite (Ald) (x5, pp); D) lithiophilite and sicklerite replaced by varulite (Vr) and later by lipscombite (lcb) (x2, pp); E) Colorless hureaulite II (HurII) cuts phosphosiderite violet aggregates (Psh) and jahnsite (Jhn) (x20, pp); F) zircon with eosphorite (Eos) (x5, pp); G) eosphorite cuts albite $(\mathrm{Ab})(\mathrm{x} 2, \mathrm{xp}) ; \mathrm{H})$ fine grain aggregate of albite replacing a sicklerite crystal $(\mathrm{x} 2$, $\mathrm{pp)}$. 


\section{Metasomatic phosphates}

The appearance of a metasomatic stage related to $\mathrm{Na}$ enrichment is characterized by alluaudite and varulite replacing sicklerite and triplite, respectively, distributed along thin veins and fractures. They display pale green or yellow hypidomorphic crystals up to $1 \mathrm{~mm}$ long with very short prismatic habit and visible exfoliation (Fig. 5c). Regarding mineral chemistry, alluaudite $\mathrm{Mn} /(\mathrm{Mn}+\mathrm{Fe})$ ratio are close to 0.71 , the same observed for Fe-rich lithiophilite and sicklerite.

\section{Secondary phosphates}

Besides previous phosphates, a great number of idiomorphic phosphates are replacing earlier phases displaying radial aggregates and infilling veins or cavities. Hureaulite is one of the most abundant secondary phase, occurring as fibrous crystals distributed in millimetric veins. Two generations are distinguished: hureaulite I replaces sicklerite or triphylite - lithiophilite following exfoliation discontinuities, while hureaulite II, latter in origin, overlaps other supergenic phosphates (Fig. 5d). Eosphorite replace $\mathrm{Mn}-\mathrm{Fe}$ primary phosphates in association with other Mn-bearing phosphates and hureaulite. Chemical analyses revealed extreme Mn-rich compositions near to eosphorite end-member. Its formation can be attributed to different processes than those related to the formation/crystallization of the pegmatite. Whiteite and jahnsite occur as yellow crystals filling veinlets inside previous phosphates. Under microscope, they show high birefringence and typical polysynthetic twinned. Fe-rich supergenic phosphates such as lipscombite, phosphosiderite (Fig. 5d) and mitridatite (Fig. 5e) form fine grain patinas and crusts or aggregates above of precursor phosphates. They present different colors in hand sample (lipscombite reddish orange, phosphosiderite purple and mitridatite greenish brown) and with the use of electron microprobe analyses, assure their identified (Table 1). Moreover, serrabrancaite also has been observed as hydrous manganese phosphate. It can be confused with $\mathrm{Mn}$ or Fe oxides suggesting that it can be more abundant. Serrabrancaite was discovered in Serra Branca pegmatite, located few kilometers SE, as alteration product of triplite (Witzk et al., 2000).

\section{Zircon}

Zircon crystals are observed in both intermediate zones often altered by uraninite veins and galena (Fig. 4f). As pointed out by London (2008), $\mathrm{Hf} / \mathrm{Zr}$ ratio corresponds to another interesting indicator of the evolution of the pegmatites. Hence, analyses reveal low $\mathrm{Hf}$ content (up to $5 \% \mathrm{HfO}_{2}$ ).

\section{DISCUSSION AND CONCLUSIONS}

\section{Paragenetic sequence}

During the first intermediate zone formation, primary phosphate growth occur during the pegmatite formation concurrently with silicate crystallization, both from parental pegmatite magma. It is supported by in Boqueirão, where primary phosphates identified are triphylite, lithiophilite, sarcopside, triplite, amblygonite, and sicklerite. The latter formed from $\mathrm{Li}^{-}$ leaching alteration of lithiophilitetriphylite and considered a primary phase according to Corbella and Melgarejo (1990). Subsequently to pegmatite consolidation, late Nametasomatism stage is expressed by late albite units formed from metasomatic exchange processes and by Na-rich phosphates crystallization such as alluaudite and varulite deriving from 
primary triphylite-ferrisicklerite oxidation (Fransolet and Hatert, 2004; Roda-Robles et al., 2010; Hatert et al., 2011). Secondary hureaulite, eosphorite, whiteite, jahnsite, phosphosiderite, lipscombite, mitridatite and serrabrancaite are found as veins and porosity infillings, patinas or crusts. They may have crystallized by percolating meteoric waters at depth or by an aqueous fluid remaining after pegmatite consolidation producing a widespread hydrothermal alteration of primary phosphates.

\section{Evolution of pegmatite}

The study of geochemical ratios in major minerals may provide an approximation of pegmatite evolution degree. The most used ratios are $\mathrm{Mn} /(\mathrm{Mn}+\mathrm{Fe})$ in primary phosphates and garnet, Li-Rb-Cs in feldspars and muscovite or $\mathrm{Hf} / \mathrm{Zr}$ in zircon (London, 2008), all increasing when fractionation process advances. In spite of the presence of abundant Mn-poor triphylite, Boqueirão primary phosphates show $\mathrm{Mn}$ enrichment as observed by constant $\mathrm{Mn} /(\mathrm{Mn}+\mathrm{Fe})$ values around 0.70 which suggests slight evolution of early pegmatite magma. Sarcopside intergrowth inside Mn-triphylite has similar $\mathrm{Fe}$ content suggesting its primary origin. However, primary lamellae texture can be absolutely overprinted due to secondary phosphate alteration. It was studied in detail by Roda et al. (2004) and Hatert et al. (2007) in the Cañada pegmatite. Lithiophilite - triphylite $\mathrm{Mn} /(\mathrm{Mn}+\mathrm{Fe})$ ratio remains constant in ferrisicklerite - sicklerite replacements but also in metasomatic alkaline phosphates as alluaudite and varulite. This behaviour suggests that early subsolidus stages after pegmatite crystallization and albitization process would be partially closed. $\mathrm{Mn} /(\mathrm{Mn}+\mathrm{Fe})$ ratio in secondary phosphates is not constant pointing out that they have been formed by the entrance of late hydrothermal or supergenic fluids (Corbella and Melgarejo, 1990) and they do not keep any relationship with pegmatite consolidation.

The abundance of phosphate minerals demonstrate that the parental pegmatite magma was enriched in $\mathrm{P}$ but depleted in other volatiles like $\mathrm{F}$, expressed by absence of F-rich mineral such as fluorite or topaz and it would also explain triplite and amblygonite scarcity observed in Cap de Creus pegmatite field (Corbella and Melgarejo, 1990). Hence, high $P$ activity of pegmatite magma is represented by scarcity of Li-bearing silicate (Černý and Ercit, 2005). Ferromagnesian silicates such as schorl and almandine prevail in the outer zones of Boqueirão. Their ubiquity is a characteristic proxy of low evolved magmas (London, 2008) in conjunction with green alkali-poor beryl suggesting high $\mathrm{Fe}$ contents in pegmatitic melt (Gonçalves, 2008). Low content of Hf analysed in zircon correspond to low $\mathrm{Hf} / \mathrm{Zr}$ ratio also indicative of low degree of pegmatite evolution (Černý et al., 1997; London, 2008). Nevertheless, the occurrences of beryl and scarce Ta-Nb minerals suggest that Boqueirão pegmatite has enough degree of evolution to belong to beryl-columbitephosphate subtype, according to Černý and Ercit (2005). Consequently, it has economical potential and metallogenic interest.

\section{Acknowledgements}

This research was supported by SGR444 project of the Generalitat de Catalunya.

\section{REFERENCES}

Baumgartner R., Romer, R., Moritz, R., Sallet, R., Chiaradia, M., 2006. Columbite - Tantalite - Bearing 
granitic pegmatites from de Seridó Belt, Northeastern Brazil: Genetic constraints from $\mathrm{U}-\mathrm{Pb}$ dating and $\mathrm{Pb}$ isotopes. The Canadian Mineralogist, 44: 6986.

Beurlen, H., Da Silva, M.R.R, Thomas, R., Soares, D.R, Olivier, P. 2008. $\mathrm{Nb}-\mathrm{Ta}-(\mathrm{Ti}-\mathrm{Sn})$ oxide mineral chemistry as tracer of rare element granitic pegmatite fractionation in the Borborema Province, Northeastern Brazil. Mineralium Deposita, 43: 207-228.

Beurlen, H., Barreto, S., Martin, R., Melgarejo, J.C., da Silva, M.R.R., Souza Neto, J.A. 2009. The Borborema pegmatite province, NE-Brazil. Revisited. Estudos Geológicos, 19: 62-66.

Cameron, E.N., Jahns, R.H, McNair, A.H., Page, L.R. 1949. Internal Structure of Granitic Pegmatites. Economic Geologist, Monograph 2.

Černý, P. 1991a. Rare-element granitic pegmatites. Part I: anatomy and internal evolution of pegmatite deposits. Geoscience Canada, 18: 49-67.

Cerný, P., Alfonso, P., Melgarejo, J.C. 1997. Pegmatites granítiques. In: Melgarejo, J.C. (Eds): Atles d'Associacions Minerals en Làmina Prima. Edicions de la Universitat de Barcelona, Barcelona (ISBN: 84-89829-24-1) p. 129-152.

Černý, P., Ercit, T.S. 2005. The classification of granitic pegmatites revisited. The Canadian Mineralogist, 43: 20052026.

Corbella. M, Melgarejo, J.C. 1990. Características y distribución de los fosfatos de las pegmatitas graníticas de la Península del Cap de Creus (Pirineo Oriental catalán). Boletín de la Sociedad
Española de Mineralogía, 13: 169-182.

Fontan, F. 1976. Les phosphates des pegmatites de la región de Crozant (Creuse). Bulletin de la Société française de minéralogie, 99: 318-321.

Fransolet, A.M, Hatert, F. 2004. Petrographic evidence for primary hagendorfite in an unusual assemblage of phosphate minerals, Kibingo granitic pegmatite, Rwanda. The Canadian Mineralogist, 42: 697-704.

Gonçalves, A.O. 2008. Caracterización mineralógica, geoquímica $\mathrm{y}$ petrogenética de las pegmatitas graníticas de Giraúl, Namibe, Angola. $\mathrm{PhD}$ Thesis by Universidad de Zaragoza. 445 p.

Hatert, F., Roda-Robles, E., Keller, P., Fontan, F., Fransolet, A.M. 2007. Petrogenetic significance of the triphylite + sarcopside intergrowth in granitic pegmatites: an experimental investigation of the $\mathrm{Li}(\mathrm{Fe}, \mathrm{Mn})\left(\mathrm{PO}_{4}\right)-(\mathrm{Fe}, \mathrm{Mn})_{3}\left(\mathrm{PO}_{4}\right)_{2}$ system. Granitic Pegmatites: The state of the Art - International Symposium, Porto, Portugal.

Hatert, F., Ottolini, L., SchmidBeurmann, P. (2011): Experimental investigation of the alluaudite + triphylite assemblage, and development of the Na-intriphylite geothermometer: application to natural pegmatite phosphates. Contributions to Mineralogy and Petrology, 161: 531-546.

Lima, E.S. 1986. Metamorphism and Tectonic Evolution in the Seridó Region, Northeastern Brazil. PhD Thesis University of California.

London, D. 2008. Pegmatites. The Canadian Mineralogist, Special Publication, 10 p. 347.

London, D., Burt, D.M. 1982. Alteration of spodumene, montebrasite and lithiophilite in 
pegmatite of the White Picacho District, Arizona. The American Mineralogist 67: 97-113.

Moore, P.B. 1982. Pegmatite minerals of $\mathrm{P}(\mathrm{V})$ and $\mathrm{B}(\mathrm{III})$. In Černý (Eds): Granitic pegmatites in science and industry. MAC Short Course Handbook, 8: 267-291.

Roda, E., Pesquera, A., Fontan, F., Keller, P. 2004. Phosphate mineral associations in the Cañada pegmatites (Salamanca, Spain): Paragenetic relationships, chemical compositions, and implications for pegmatite evolution. The American Mineralogist, 89: 110-125.

Roda-Robles, E., Vieira, R., Pesquera, A., Lima, A. 2010. Chemical variations and significance of phosphates from the FregenedaAlmendra pegmatite field, Central Iberian Zone (Spain and Portugal). Mineralogy and Petrology, 100: 24-34.

Soares, D.R., Beurlen. H., De Brito Barreto. S, Da Silva. M.R.R,
Ferreira. A.C.M. 2008.

Compositional variation of tourmaline group minerals in the Borborema Pegmatitic Province, Northeastern Brazil. The Canadian Mineralogist, 46: 10971116.

Van Schmus, W.R., Brito Neves, B.B., Hackspacher, P., Fetter, A.H., Dantas, E.L., Babinski, M. 2003. The Seridó Group of NE Brazil, a late Neoproterozoic preto syncollisional basin in West Gondwana: insights from SHRIMP U-Pb detrital zircon ages and $\mathrm{Sm}-\mathrm{Nd}$ crustal residence (TDM) ages. Precambrian Research, 127: 287-327.

Witzke, T., Wegner, R., Doering, T., Pöllmann, H., Schuckmann, W. $2000 . \quad$ Serrabrancaite, $\mathrm{MnPO}_{4} \cdot \mathrm{H}_{2} \mathrm{O}$, a new mineral from the Alto Serra Branca Pegmatite, Pedra Lavrada, Paraiba, Brazil. The American Mineralogist, 85: 847-849. 